\title{
Monitoring energy audit for energy savings using non cost technique at electronics company
}

\author{
M.N. Mohd Foudzi1', M.Y. Taib ${ }^{1}$, A.S. Arnizam Shah², and A.R. Yusoff1, \\ ${ }^{1}$ College of Engineering, Universiti Malaysia Pahang, 26300 Pahang, Malaysia. \\ ${ }^{2}$ TT Technologies Corporation Sdn Bhd, Jalan Tanjung Api, 26050, Kuantan, Pahang, Malaysia
}

ABSTRACT - Energy is essential element for profit and productivity growth in industry and directly measuring the standard of living for a country. The profit and lost in industry depends on energy consumption in each production process line from raw materials until finish product. In this paper, energy consumption was monitored and audited for each section of production line at the electronic company in Malaysia. The energy consumption was analysed based on electrical bill and then the power consumption has been measured based on energy audit process using power analyser. It is monitored that the energy audit for the whole company to search and find out the possiblity of non cost energy saving technique. From 10 locations analyses, 3 locations are recognised as the main soursces contribite to high energy consumption. Majority energy relates to compressor room (29\%), busbar $15(20 \%)$ and busbar $16(14 \%)$ relates to chiller room that supply the air conditioning system in the company. The energy audit can provide overall veiw on energy utilisation for proposing the suitable non cost technique to reduce energy and improve the profit in this electronic company.
ARTICLE HISTORY

Revised: $30^{\text {th }}$ March 2021

Accepted: $31^{\text {st }}$ March 2021

\section{KEYWORDS}

Energy consumption

Power utilization

Energy audit

Energy savings techniques

\section{INTRODUCTION}

Energy is expensive and important commodity in any manufacturing industry [1]. It is essential for industry to develop an energy audit to search the energy conservation opportunities and methods for energy consumption reduction. Such energy auditing would be unique, depending on type and need of the specific industry. The auditing kit needs essential tools such as sub division of the production system of any commodity in several blocks or departments and a reliable metering or measurement systems in each block. The reasons to have the subdivision or smaller pockets of a particular stage of production is to pinpoint the location of the higher energy consumption where greater attention is needed. The consumption of energy in Malaysia and around world has drastically increased and it is also required to be checked by any means [1]. In last several decades, industrial energy audit is in demand to reduce the increasing energy price and also for sustainable future. The importance of energy audit is magnified because energy spending is a major expense to industries. As the cost of energy is continuously increasing, this growing trend should continue [2].

Energy audit, similar to financial accounting process, is a process of examining an energy account, checking the way energy is used and identify areas where wastage can be minimized [2,3]. In manufacturing industry for Malaysia, the highest of $50 \%$ energy consumption is attributed by production operations followed by the facility heating, ventilating, and air-conditioning (HVAC) system. The integrated energy demand from both systems is influenced by major energy cost for the overall manufacturing plant. In the most plant operation, the two major sources of energy consumption are loosed in electrical connection during peak hours. Since production operations in two shifts of peak and off peak, this is caused the facility HVAC control is highly coupled in energy dynamic demands and energy consumption. By integrating the dynamic productivity and HVAC are challenges to ensure the improvement of energy efficiency. The difficulty due to these two dynamic systems behaviours of both naturally random [3]. The production systems of electronic components have random downtime events that affect machines at different times and 40 percent production lines, while the HVAC has random environment and internal loads that contributes to 50 percent of energy utilization.

Energy audit contains much valuable information such as energy consumption, identification of equipment is which are high energy intense, finding energy saving possibilities and calculation of cost benefit [4-5]. Research efforts in the field of energy management covers different aspects. A critical review of the state of the art of manufacturing processes energy efficiency [4] at different levels (process, machine, line and plant). At machine level, energy management focuses on enhancing energy efficiency by optimally selecting cutting conditions [5]. Monitoring approaches for energy consumption of machine tools, and accordingly obtaining energy performance KPIs in real time was reported [4]. Value stream mapping was used to analyze the value-added vs. nonvalue added energy use in machining cycles [6]. On the operational level, a study by Suwa [7] shows that considerable amounts of energy are wasted in non-value added activities such as equipment idle states and other nonmachining activities. This can be attributed to underutilization of machines, unplanned maintenance activities and scheduling problems [8,9]. It was shown that there are significant opportunities 
for energy saving through better management of the equipment without major technological or setup modifications $[10,11]$.

At ABC electronic company, the current energy used of $165 \mathrm{MWh}$ per month for electricity power utilization contributes to the cost about RM120k per month that worth to total cost almost RM1.4 million per year. The energy saving opportunity strategies can be utilized for the production line, integrating with high energy demand for the HVAC systems [1-3]. The energy audit technique can recognise the major source of energy during the operation of production line $[4,10,11]$. From the energy audit process and analysis, the improvement can be proposed using non cost technique to reduce energy utilisation for this ABC electronics company.

\section{METHOD FOR AUDITING TECHNIQUE}

Energy audit is an examination of the energy consumption of the equipment or system to ensure that energy is being used in very efficient. There are two types of energy audit have been implemented in this process namely walkthrough/preliminary and detail analysis [1] as describe in flowchart in Figure 1.

Walk-through audit is a process used to establish an overall picture of the potential of energy savings through visual inspection of the premise. This includes air conditioning system, lighting, metering, building automation, building maintenance and other factors affecting energy consumption of the building. Usually, simple instruments such as a clamp amp meter, thermometer, humidity meter and lux meter serve the purpose.

The detailed energy audit involves in-depth investigations into how the energy is currently being consumed, current performance of the existing systems and identification of various potential energy conservation measures [7]. It also gives the estimated cost and simple payback periods for all recommendation and suggestion. There are ten point of measuring location had identified as a main contribution to higher power consumption at ABC industry. Table 1 and 2 tabulates 7 points have been selected at the ground floor and 3 points at the first floor.

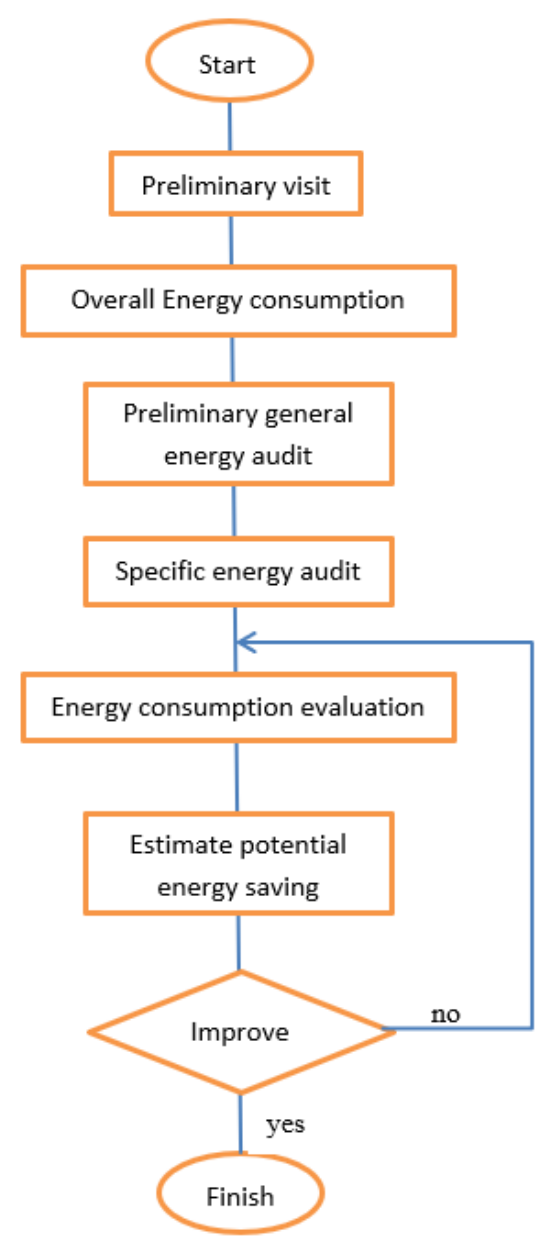

Figure 1. Two level energy audit for ABC company.

After identifying the location of measurement, industry personal (Electrical Chargeman) who is the certified person has been informed to install the power analyser. There are two brands of power analysed used in this measurement which is Kyoritsu power meter model 6300 and Chauvin Arnoux power model PEL103. Data measurement collected at the planning location within 2 weeks period of duration. Measuring tools will record all data for every 2 minutes and there are 720 data recorded in a day. After 2 weeks of measurement, the data have been analysed to obtain daily average power, 
total power usage and power trend. Data from power analysers can be analysed the detail daily average power, total power usage and power trend.

Table 1. Ground floor point measurement

\begin{tabular}{cccc}
\hline Point & From & Connected to & \multicolumn{2}{c}{ Location } \\
\hline 1 & Busbar 13 & AC Panel 3 Unit & Near to Varnish Room \\
& & AC Panel 2 Unit & HR Office \\
2 & Busbar 14 & AC Panel 3 Unit & Training Room \\
& & AC Panel 3 Unit & Near to 500KG Hoist Lift (OJT \\
3 & Substation & ASL (IR Reflow Oven) & Room) \\
4 & Substation & & IR Reflow Oven \\
5 & Substation & & Office Moulded \\
6 & Substation 1 & & Grinding Area \\
7 & Busbar 1 & Production Area & Compressor Room \\
\hline
\end{tabular}

Table 2. First floor point measurement

\begin{tabular}{cccc}
\hline Point & From & Remarks & \multicolumn{2}{c}{ Location } \\
\hline 8 & Busbar 15 & AC Panel 2 Unit & PDE Raw Material Store \\
& & AC Panel 3 Unit & Office Manager near to the stairs \\
& & AC Panel 4 Unit & Finance Meeting Room \\
9 & Busbar 16 & Roof Top, Cooling Tower & Lift Interior \\
& & Panel & Lift Interior \\
& & DB CNC & CNC Machine Room \\
& Busbar 7 & DB Stripping & Wire Stripping Room
\end{tabular}

Electricity power consumption was measured and analysed to identify power usage of the facilities and to rectify appropriate electricity saving measures. The measurement of energy consumption can be calculated by multiplying the power in watt and hour of operations together with 30 days and divided by 1000 as shown by Equation (1).

$$
\text { Power usage }(k W h)=\frac{\text { Power }(W) \times \text { Hour operation } \times 30 \text { days }}{1000}
$$

Load factor, $L F$ is commonly calculated by billing period, and is the ratio between average demand, $k W_{\text {demand }}$ and peak meter demand, $k W_{\text {meter }}$. Average demand is the average hourly draw during the billing period. Load factor is obtained based on Equation (2).

$$
L F=\frac{k W_{\text {demand }}}{k W_{\text {meter }}}=\frac{k W h}{\left(k W \times N_{\text {days }} \times 24 \frac{h r s}{d a y}\right)}
$$

$k W_{\text {meter }}$ is the total hours in the billing period or $N_{\text {days }}$ is the number of days in the billing period. Load factors are represented as either a ratio (from 0 to 1 ) or as a percentage (from 0 to $100 \%$ ).

Power factor, $P F$ is an index used to measure the efficient use of electricity with measured on a range of 0 to 1 . For customers taking supply at $33 \mathrm{kV}$ or below, the value of the power factor to be maintained is more than 0.85 . If the power factor less than 0.85 resulting power factor surcharge. For customers taking supply at $132 \mathrm{kV}$ or below, the value of the power factor to be maintained is more than 0.90 . If the power factor less than 0.90 resulting PF surcharge. A higher $P F$ index more than 0.85 or 0.90 , indicate an efficient level of electricity usage. On the other hand, a low $P F$ index (lower 0.85 or 0.90 ) shows an efficient use of electricity for indicating electricity wastage. 


\section{RESULTS AND DISCUSSION}

During the energy audit, all the relevant parameters has been considered such as total power, peak unit, off peak unit, maximum demand, load factor and power factor variation of plant from the electricity bill from ABC company. For this company, industrial tariff E2 has been used by Tenaga National Berhad (TNB) as a calculation of electricity cost as tabulated in Table 3. The tariff is different for peak and off-peak is 35.50 sen per $\mathrm{kWh}$ and 21.90 sen per $\mathrm{kWh}$.

Table 3 Industrial tariff E2 for medium voltage peak/off peak

\begin{tabular}{ll}
\hline Tariff Category & E2 industry \\
\hline For each kilowatt of maximum demand per month during the peak period & $37.00 \mathrm{RM} / \mathrm{kW}$ \\
For all $\mathrm{kWh}$ during the peak period $(0800 \mathrm{hrs}-2200 \mathrm{hrs})$ & $35.50 \mathrm{sen} / \mathrm{kWh}$ \\
For all kWh during the off-peak period $(2200 \mathrm{hrs}-0800 \mathrm{hrs})$ & $21.90 \mathrm{sen} / \mathrm{kWh}$ \\
The minimum monthly charge is RM600 & \\
\hline
\end{tabular}

Figure 2 shows electrical bill and demand for this company in 2018. The maximum demand is measured in kilowatt $(\mathrm{kW})$. The maximum demand is the highest level of electricity demand been recorded in a particular period usually for a month period. Maximum demand for any month should be deemed to be twice the largest number of kilowatt (kWh) supplied during any consecutive thirty minutes in that month. The current energy used of $165 \mathrm{MWh}$ average per month for electricity power utilization that contributes to cost average RM120k per month that worth to total cost almost RM1.4 million per year. Hopefully, this electronic company can improve their energy efficiency.

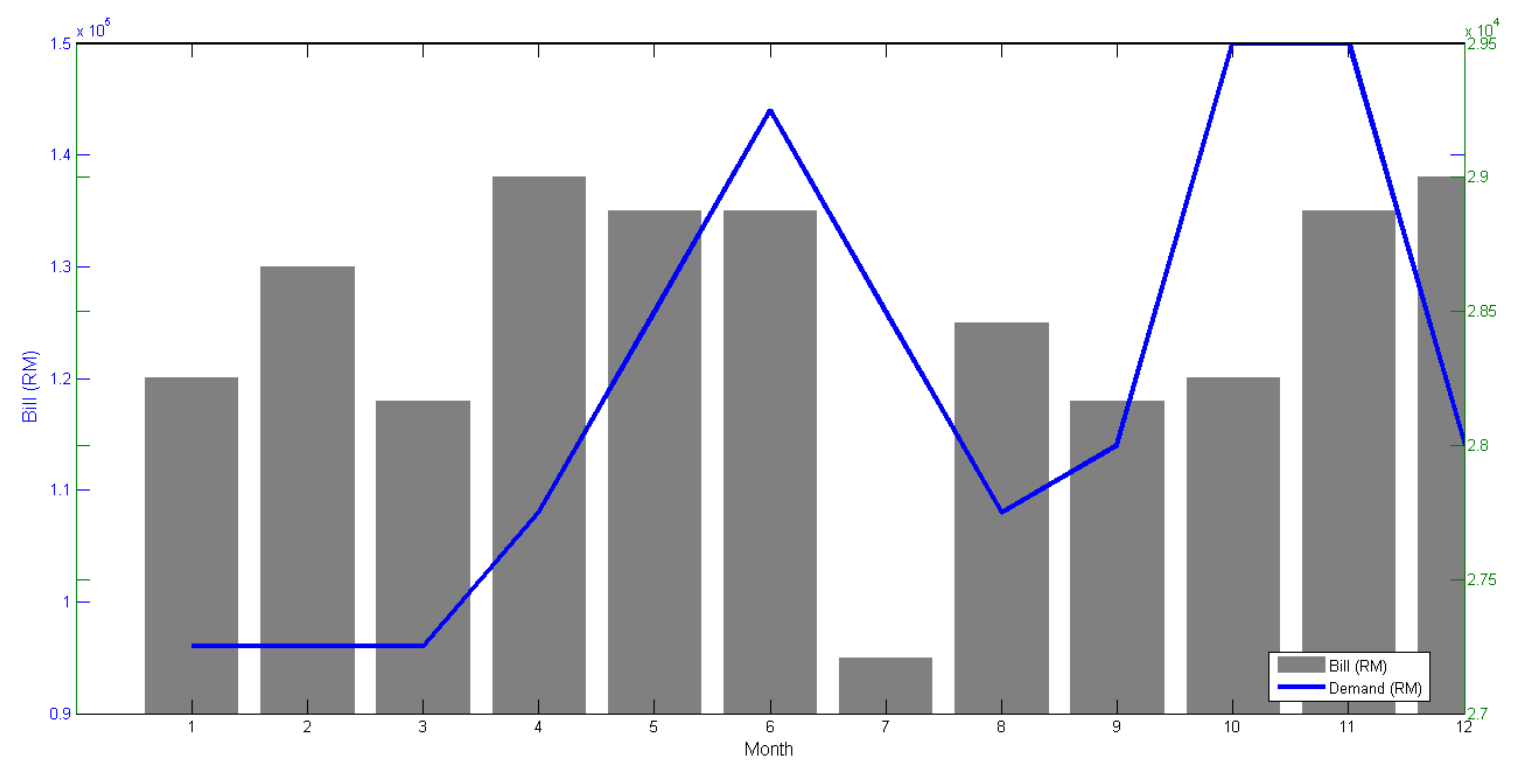

Figure 2 Electrical bill and demand for electronic company in 2018

The utility bill tracking and analysis is at the centre of rigorous energy management practice. Reliable energy management decisions can be made based upon analysis from an effective utility bill tracking system. Figure 3 shows LF and PF for this company in 2018 . If the LF greater than 0.75 , it represents nearly constant loads. This show the equipment is likely not turned off at night and peak usage (relative to off peak usage) is low. While low LF that lower than 0.25 belongs to meters that have very high power draws relative to the sample. These meters could be associated with chillers or electrical heating equipment that is turned off for much of the day. Low LF can also be associated with buildings that shut off nearly all equipment during non-running hours. From Figure 3, it shown that load factor within range between 0.25 and 0.75 , while PF consistently maintain at high than 0.85 index to avoid the energy surcharge from the provider. It is shown that no additional charges in monthly electricity bill as there is no PF surcharge $[1,12,13]$. These extending the lifespan of electrical appliances and reducing the electricity wastage for electrical installations at customers, premises. It conserves the environment by lowering fuel usage and helps the country reduce carbon dioxide. 


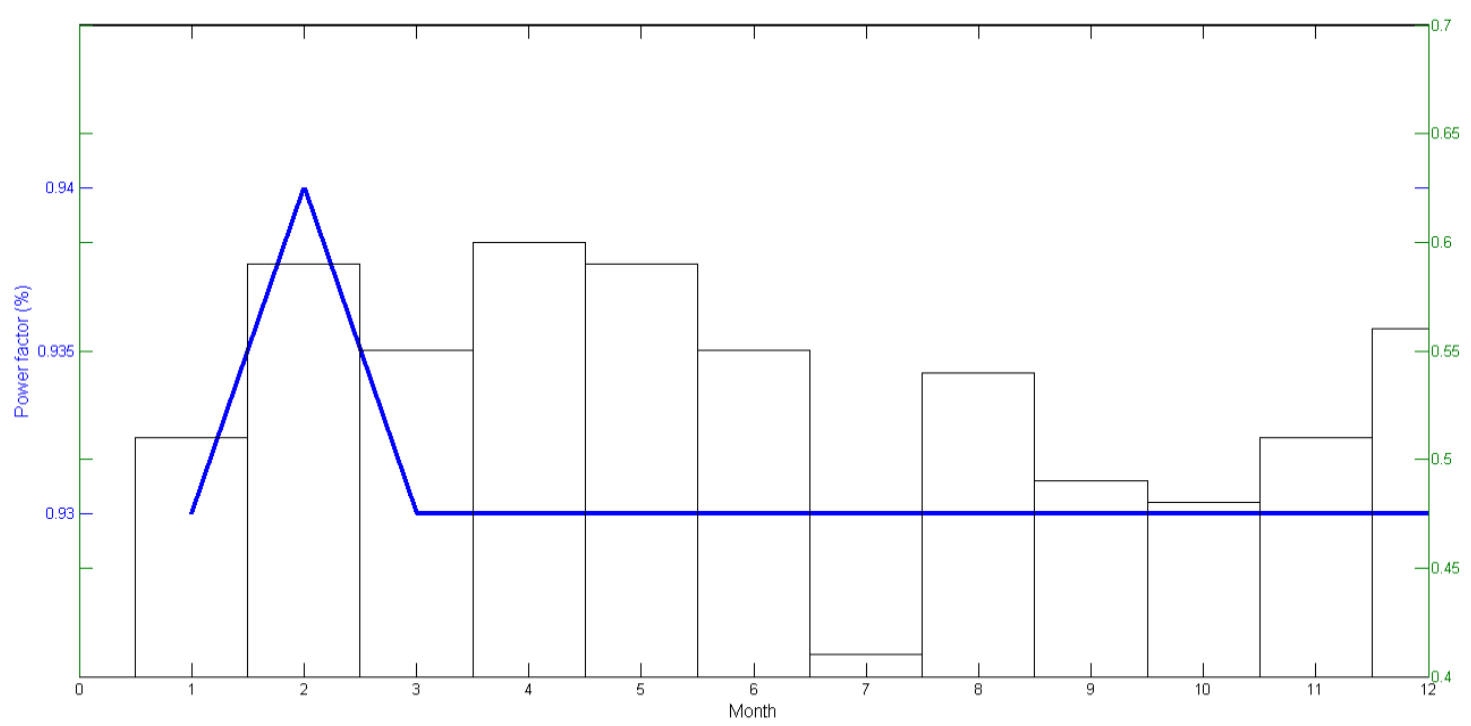

Figure 3 Power factor and Load factor for company in 2018

Table 3 shows the summary of the electricity data measured for both ground floor and first floor in the electronic company. All measured point has to be analysed to determine which is contribute the highest energy consumption. There are 7 point measurement locations have been identified and analysed as highest power contribution to this industry, as shown in Figure 4. During 2 weeks data measurement, the most equipment is used during peak hour which is highest rate compared to off-peak time (Figure 4 ).

Figure 5 shows $26 \%$ of power usage at the ground floor is came from substation 1 monthly amount of RM21,444, followed by busbar 15 with $20 \%$ at amount of RM15,258 monthly. Busbar 16 was recorded with RM10,426 (14\%) and busbar 14 with amount of RM8,152 (11\%). Busbar 13, Busbar 1 and Good hoist lift was recorded as RM7,994, RM5,368 and RM3,518, respectively.

From all data summary, 3 locations have been selected for further monitoring of energy consumption because there were recorded. The highest power usage among all data are compressor room, busbar 15 and busbar 16. Figure 6a shows electrical energy consumption at compressor room. The compressor room summary results are average power of 105916 $\mathrm{W}$, total power of $36595.26 \mathrm{~kW}$ and produce the electricity amount of RM 10722.93. Figure 6b shows the energy consumption at Busbar 16. Busbar 16 summaries the results of average power is $52944 \mathrm{~W}$, total power is $16788.28 \mathrm{~kW}$ and gives the electricity amount of RM 5213.58. Figure 6c shows the electrical energy consumption at busbar 15 . Busbar 15 data summaries that the average power is $77400 \mathrm{~W}$, total power is $25379.43 \mathrm{~kW}$ and the electricity amount is RM 7629.15 .

Table 3. Energy audit summary

\begin{tabular}{|c|c|c|c|c|c|c|c|c|c|c|}
\hline \multirow{2}{*}{ No } & \multirow{2}{*}{ Location } & \multirow{2}{*}{$\begin{array}{c}\text { Average } \\
\text { power }(\mathbf{W})\end{array}$} & \multirow{2}{*}{$\begin{array}{c}\text { Highest } \\
\text { power }(\mathrm{W})\end{array}$} & \multirow{2}{*}{$\begin{array}{c}\text { Daily } \\
\text { Highest } \\
\text { power }(\mathbf{W})\end{array}$} & \multicolumn{2}{|c|}{ Total Power (kWh) } & \multicolumn{2}{|c|}{ Amount } & \multirow{2}{*}{$\begin{array}{c}\text { Total Amount in } \\
2 \text { weeks }\end{array}$} & \multirow{2}{*}{ Daily amount } \\
\hline & & & & & Off Peak & Peak & Off Peak (RM0.219) & \begin{tabular}{|l|} 
Peak (RM 0.355) \\
\end{tabular} & & \\
\hline 1 & Busbar 13 & 46100 & 122000 & 57800 & 950.52 & 10671.83 & RM208.16 & $\mathrm{RM} 3,788.50$ & RM3,996.66 & RM62.17 \\
\hline 2 & Busbar 14 & 37412 & 124293 & 55054 & 2837.53 & 9732.80 & RM621.42 & RM3,455.14 & RM4,076.56 & RM4.68 \\
\hline 3 & ASL & 711 & 8510 & 968 & 115.24 & 113.30 & RM25.24 & RM40.22 & RM65.46 & RM4.68 \\
\hline 4 & Good hoist lift & 16736 & 49970 & 22600 & 1513.50 & 4022.56 & RM331.46 & RM1,428.01 & RM1,759.47 & RM28.41 \\
\hline 5 & Grinding area & 3830 & 33100 & 6230 & 428.12 & 856.41 & RM93.76 & RM304.03 & RM397.78 & RM28.41 \\
\hline 6 & $\begin{array}{l}\text { Substation } 1 \\
\text { (Compressor room) }\end{array}$ & 105916 & 168000 & 147000 & 16679.30 & 19915.96 & $\mathrm{RM} 3,652.77$ & RM7,070.17 & RM10,722.93 & RM765.92 \\
\hline 7 & Busbar 1 & 26017 & 63739 & 40731 & 2695.10 & 5898.20 & RM590.23 & RM2,093.86 & RM2,684.09 & RM191.72 \\
\hline 8 & Busbar 15 & 77400 & 171000 & 114000 & 10151.11 & 15228.32 & RM2,223.09 & RM5,406.05 & RM7,629.15 & RM544.94 \\
\hline 9 & Busbar 16 & 52944 & 137697 & 84827 & 5487.20 & 11301.08 & RM1,201.70 & RM4,011.88 & RM5,213.58 & RM372.40 \\
\hline 10 & Busbar 7 & 8320 & 27300 & 12800 & 792.09 & 1963.11 & RM173.47 & RM696.90 & RM870.37 & RM62.17 \\
\hline
\end{tabular}




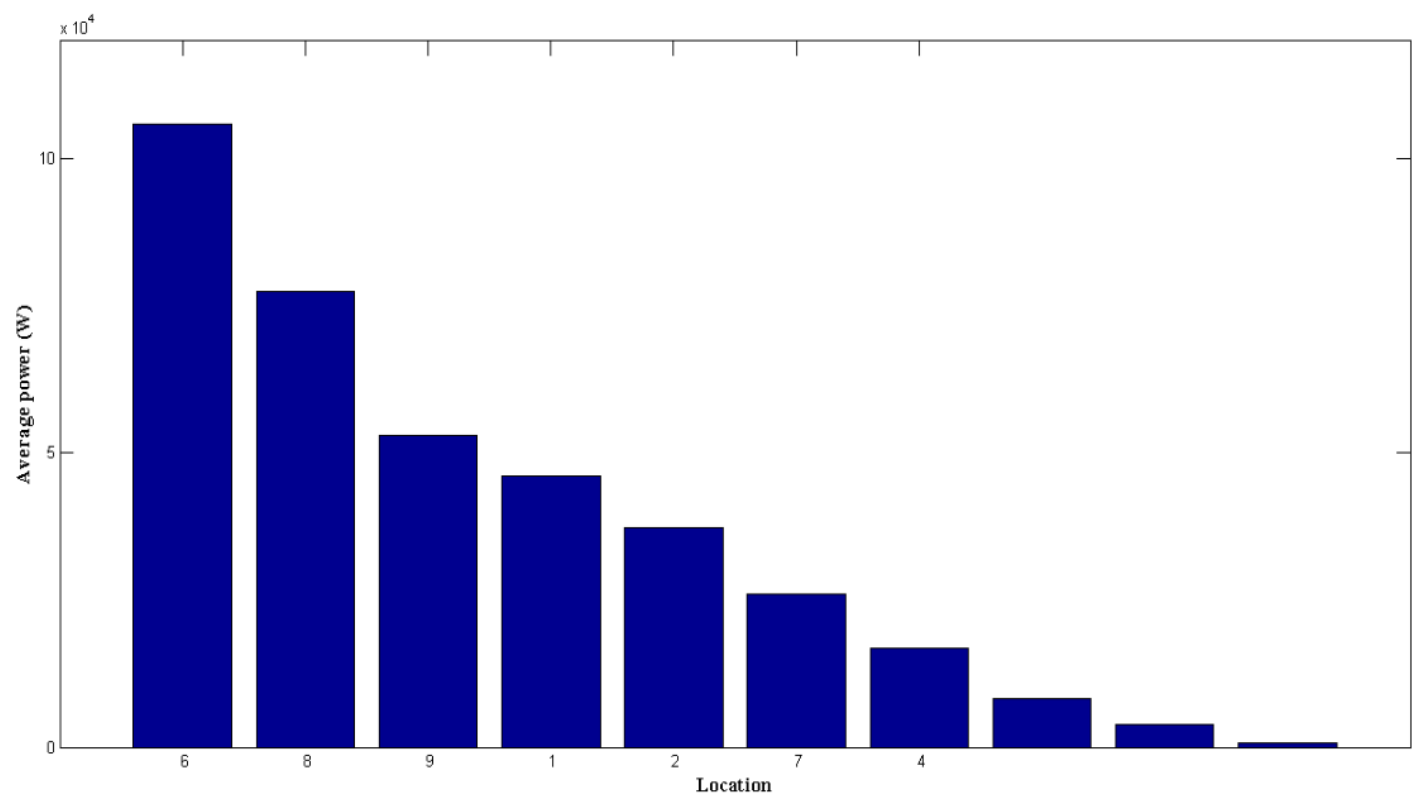

Figure 3. Location for power usage in the electronic company

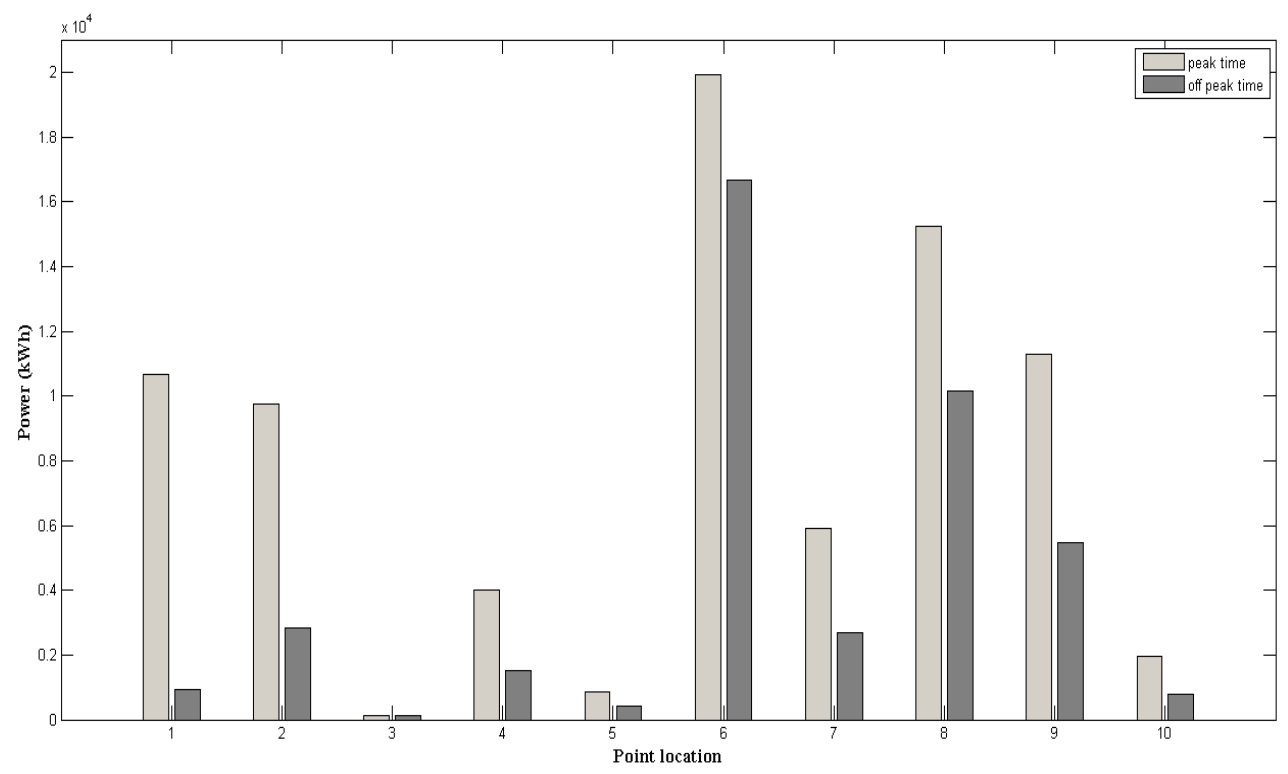

Figure 4 Power usage in peak and off peak hours for 10 locations 


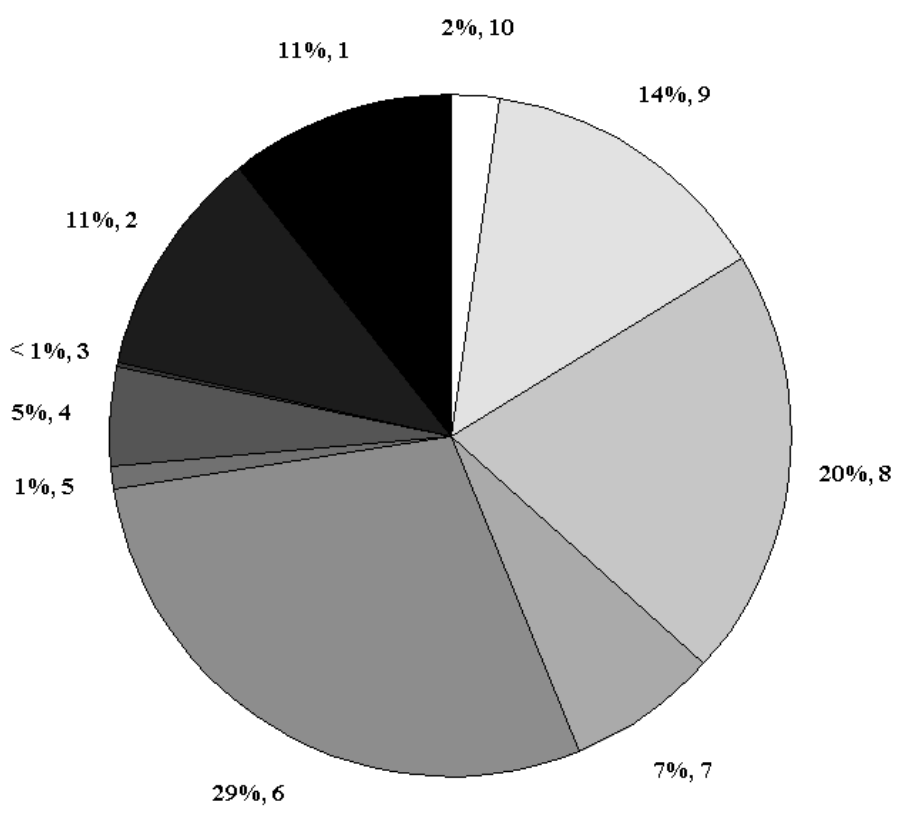

Figure 5. Monthly electricity bill percentage for 10 locations

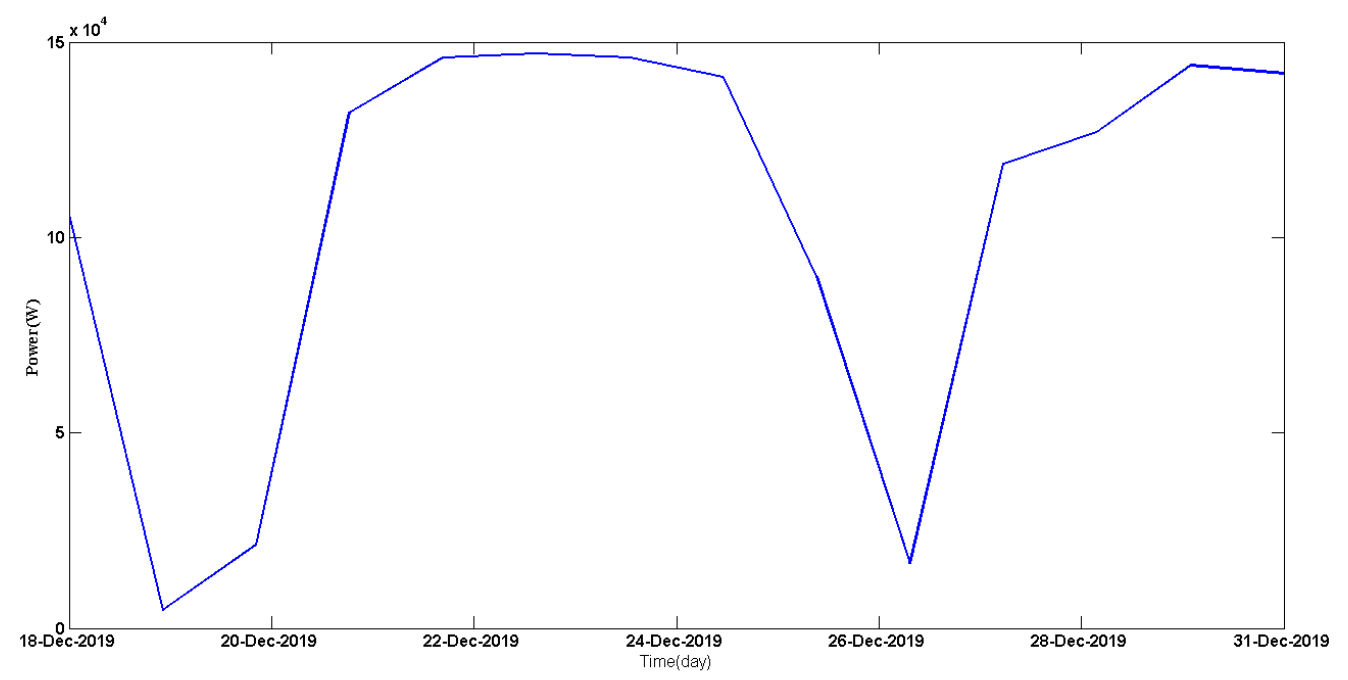

Figure 6a Two weeks average power for Compressor room 


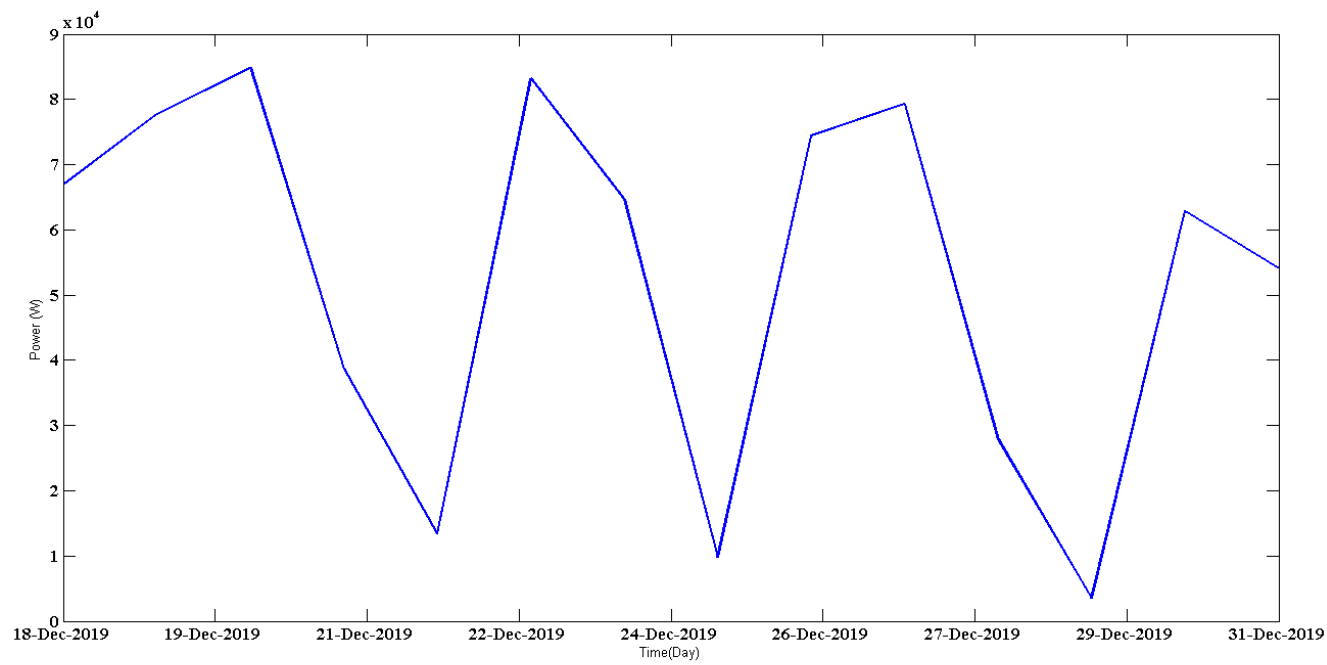

Figure 6b Two weeks average power for Busbar 16

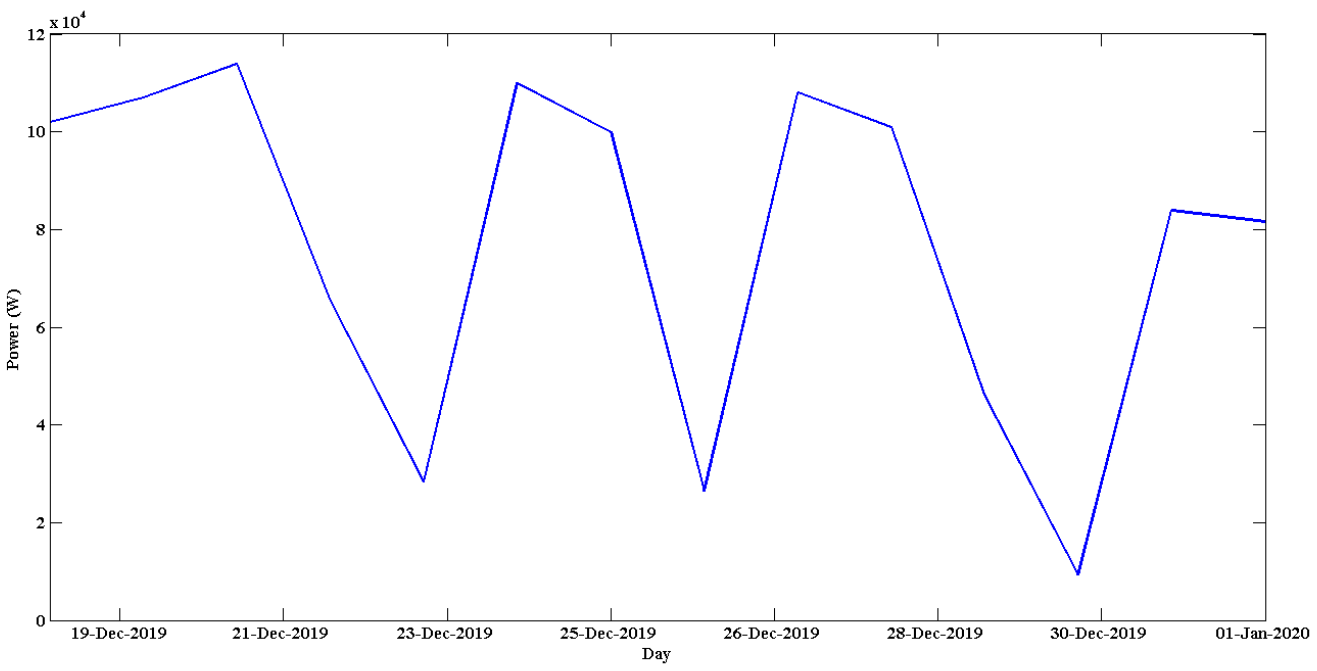

Figure 6c. Two weeks average power for Busbar 15

There are few activities could be carried out by costumers that assist in reducing maximum demand charges [1,12,14]. First, practise the demand side management such as peak shift which is shifting their peak operation or assumption to off peak period as maximum demand charges is not applicable during peak or off-peak tariff. Second, opting for any promotional scheme offered by TNB relating to maximum demand such as Sunday tariff rider scheme. Third, starts your motor or equipment is stages or during off peak period.

\section{CONCLUSION}

Based on the analysis, it can be concluded that there are three main items that contribute to the energy usage at this electronic company. First, the source from the compressor room (29\%) for compress air systems and another two location from Bushbar $15(20 \%)$ and Bushbar $16(15 \%)$, as electrical power for air conditioning systems. The energy audit is an effective way to identify the energy used in and energy loss in the systems for future improvement. From the results, several saving possibilities as non-cost technique for energy conservation opportunity such as increase air condition temperature and repair leakage compressor. Additionally, energy audit can identify the poor-quality equipment or the old equipment which can cause energy loss. In the future, by performance the cost-based analysis, the energy consumption is analysed effectively.

\section{ACKNOWLEDGEMENT}

The authors would like to thank the MTUN Industry Research Grant Scheme for its financial support (Grant No. RDU121204). 


\section{REFERENCES}

[1] Kettha, National Energy Efficiency Action Plan Report, 2014, Ministry of Energy, Malaysia Green Technology and Water Malaysia.

[2] Bunse, K., Vodicka, M., Schönsleben, P. , Brülhart, M. and Ernst, F.O., Integrating energy efficiency performance in production management - gap analysis between industrial needs and scientific literature, Journal of Cleaner Production Volume, Vol. 19 No. 6-7, pp. 667-679, 2010

[3] Brubdage, M.P., Li, Y, Xiao, G and Arinez, J., Energy efficiency management of an integrated seriel production line and HVAC systems, IEEE Transactions on Automation Science and and Engineering, Vol 11 No. 3, pp.789-797, 2014.

[4] Despeisse, M., Mbaye, F., Ball, P.D. and Levers, A., Emergence of sustainable manufacturing practices, Production Planning and Control, Vol. 23 No. 5, pp. 354-376, 2012

[5] Meo, I, Papetti, A, Gregori, F, Germani, M, Optimization of energy efficiency of a production site: a method to support data acquisition for effective action plans, Procedia Manufacturing, Vol. 11, pp. 760-767, 2017.

[6] Hajmohammad, S., Vachon, S., Klassen, R.D. and Gavronski, I. Lean management and supply management: their role in green practices and performance, Journal of Cleaner Production, Vol. 39, pp. 312-320, 2013.

[7] Suwa, H. And Samukawa, T. A new framework of energy-efficient manufacturing systems based on energy load profiles, Procedia CIRP 41, pp. 313-317, 2016.

[8] Schönsleben, P., Vodicka, M., Bunse, K. and Ernst, F.O., The changing concept of sustainability and economic opportunities for energy-intensive industries, CIRP Annals - Manufacturing Technology, Vol. 59 No. 1, pp. 477-480, 2010.

[9] Faccio, M. and Gamberi, M., Energy saving in operations management through variable-speed drive technology environmental versus economic convenience, International Journal Services and Operations Management, Vol. 26 No. 1 , pp. 68-96, 2017.

[10] Lunt, P. and Levers, A., Reducing Energy Use in Aircraft Component Manufacture - Applying Best Practice in Sustainable Manufacturing, SAE AeroTech Congress. Warrendale, PA: SAE International, 2011.

[11] Rosenqvist, J, Thollander, P and Rohdin, P. Industrial Energy Auditing for Increased Sustainability - Methodology and Measurements, 2012, in Sustainable Energy, InTech Publisher, ISBN: 978-953-51-0912-9.

[12] Fabian Kellera, Gunther Reinharta. Energy Supply Orientation in Production Planning Systems, Procedia CIRP 40, pp. 244249, 2016.

[13] Bonnel Mejía-Maya, Vanessa Sierra-Zuluaga and Javier Darío Fernández-Ledesma. Proceedings of the International Conference on Industrial Engineering and Operations Management, Bogota, Colombia, October 25-26 2016, 2017

[14] Ahmed M. Marzouka, Hoda A. ElMaraghya, Waguih H. ElMaraghy, Effect of changing operating policies on energy use consumption, Procedia CIRP 41, pp. 301-306, 2016. 